\title{
DRAMATURGIA E PERFORMANCE POPULAR: Vargas, de Dias Gomes, e os desfiles das escolas de samba ${ }^{1}$
}

\author{
Dramaturgy and popular performance: \\ Vargas, by Dias Gomes, and the parade of Escolas de \\ Samba
}

\author{
Larissa de Oliveira Neves \\ Universidade Estadual de Campinas - UNICAMP
}

Resumo: O presente artigo apresenta uma análise da peça Vargas (1983), de Dias Gomes e Ferreira Gullar, a partir do folguedo no qual os autores se basearam para construir a dramaturgia: os desfiles de escolas de samba. Para tanto, apresenta rapidamente a importância do teatro musicado na história do teatro brasileiro, em seguida comenta a estrutura espetacular dos desfiles, para então analisar a peça dentro dessa correspondência.

Palavras-chave: Vargas; teatro musicado; teatro popular.

Abstract: This paper presents an analysis of the piece Vargas (1983), written by Dias Gomes and Ferreira Gullar, using as basis the popular party that the authors used to build the playwriting: the samba school parades. It presents the importance of the musical theater for the history of Brazilian theater, comments the spectacular structure of the parades, and then analyses the piece using this paradigms.

Keywords: Vargas; musical theater; popular theater.

\footnotetext{
${ }^{1}$ Esse artigo faz parte de projeto financiado pela Fapesp (Fundação de Amparo à Pesquisa do Estado de São Paulo).
} 
Em 1968, pouco antes, portanto, da implementação do famigerado Ato Institucional n. 5, Dias Gomes e Ferreira Gullar escreveram o musical Dr. Getúlio, sua vida e sua glória, que foi encenado em agosto daquele ano pelo grupo Teatro Opinião, com direção de José Renato. A peça fazia parte de um movimento iniciado pelo próprio grupo no final de 1964, quando artistas do recém e violentamente desmantelado CPC da UNE uniram-se para produzir o Show Opinião, que ficou conhecido como tendo sido a primeira resposta ao golpe militar instaurado naquele ano.

Dirigido por Augusto Boal, com texto escrito a várias mãos (Oduvaldo Vianna Filho, Paulo Pontes, Augusto Boal e Armando Costa), baseado no depoimento pessoal dos musicistas Zé Ketti, Nara Leão e João do Vale - atuantes no espetáculo -, o Show fez tanto sucesso que instigou àqueles artistas e a outros a produzirem mais peças calcadas na música. Até 1969 diversos espetáculos musicados estrearam com sucesso entre Rio de Janeiro e São Paulo, como os da fase "Arena conta" (CAMPOS, 1988),
Roda Viva, de Chico Buarque; Liberdade, Liberdade, de Flávio Rangel e Millôr Fernandes; ou Morte e Vida Severina, de João Cabral de Melo Neto, musicado por Chico Buarque; entre vários outros (MERCADO, 1992).

Era como se aquele grupo de artistas de um teatro moderno consolidado, que estava sempre a investigar novas formas e conceber inovadoras maneiras de fazer teatro, em diálogo com práticas de mestres como Stanislavski e Brecht, que chegavam ao conhecimento desses artistas via leituras e professores (como Eugênio Kusnet, ou o próprio Augusto Boal), tivesse de repente descoberto uma vertente poderosa de conceber a cena, vertente essa, no entanto, que durante décadas fora o carro chefe do teatro brasileiro: o espetáculo musicado.

Desde o século XIX até meados do século $X X \quad 0$ teatro musicado correspondia à maioria dos espetáculos encenados no Rio de Janeiro e em São Paulo. Com o advento do teatro moderno e a configuração de um novo tipo de público, somado ao crescimento de formas de entretenimento como o 
cinema e a incipiente televisão, o teatro musicado sofreu uma espécie de pequeno hiato. Embora se mantivesse presente, haja vista a companhia de revista de Walter Pinto, a cena do Sudeste abriu espaço para outros tipos de peças, as modernas, muitas das quais faziam uso da música, mas sem a constituição de uma dramaturgia a serviço da mesma, como ocorriam com as antigas revistas e burletas. $O$ teatro moderno não era, no começo de sua constituição no Brasil, um teatro musicado: a música, quando existia, atuava num segundo plano dramático, secundário em relação aos diálogos falados (não cantados).

O hiato, porém, durou pouco, e o musical renasceu nas hábeis mãos daqueles artistas que marcaram a história do teatro brasileiro do final do século XX. Embora a encenação seguisse nesse período outros padrões, diferentes das convenções estabelecidas durante décadas pelo teatro musicado nacional, surpreendem, quando observamos os dois tipos de cena, as semelhanças tanto em relação à dramaturgia quanto ao espetáculo.
Os gêneros musicados como a opereta, a revista e a burleta trazem uma dramaturgia fragmentada, com quadros independentes ou quase independentes, com enredos esgarçados, e epicidade flagrante. Não foi à toa que os grupos de teatro modernos passaram a retrabalhar tais formas quando em busca do teatro épico.

Além do teatro musicado, temos uma diversidade grande de performatividades populares que também conjugam elementos extremamente ricos para pesquisa de linguagem cênica. São folguedos tais como o Boi-Bumbá, a Folia de Reis, os desfiles de escolas de samba, entre tantos outros. Dramaturgos brasileiros de todos os tempos perceberam a força de tais linguagens quando projetadas para a cena. Desde Martins Pena tais festas são relidas nos palcos brasileiros como motes de peças teatrais. Para o teatro moderno, tal como o trabalho com os gêneros musicados convencionais, os folguedos ganharam uma nova constituição formal e temática quando visitados pelo olhar da dramaturgia inovadora. 
Dias Gomes foi um dos dramaturgos do final do século $X X$ que mais se interessou por essa prática de envolver o popular sob a ótica do moderno. Algumas de suas peças dão continuidade, portanto, a essas duas dimensões de escritura cênica: o musicado e a projeção de folguedos. Para o presente artigo, discutiremos uma dessas proposições.

\section{A força da forma espetacular} popular: os desfiles das escolas de samba

A peça Dr. Getúlio, sua vida e sua glória foi reescrita em 1983, recebendo o título de Vargas, para ser encenada no Rio de Janeiro, sob direção de Flávio Rangel. Segundo os autores, a nova versão se propunha a ser mais dinâmica, visando "uma plateia já condicionada a um outro tipo de linguagem informativa decorrente dos novos meios de comunicação de massa" e "onde novos elementos como a música e a dança adquirem importância maior no processo de exposição" (GOMES, 1992, p. 32). Apesar das alterações, Vargas mantém (e talvez até exacerbe) os princípios que nortearam a criação do texto, isto é, a concepção baseada no enredo ${ }^{2}$ de um desfile de escola de samba.

$\mathrm{Na}$ "Introdução à primeira versão" da peça, os autores informam que não inventaram o formato da peça, e, se alguém o inventou, "terão sido os componentes das escolas de samba do Rio de Janeiro, o próprio povo, enfim" (GOMES, 1992, p. 27). Descrevem em seguida o que seria o formato de um enredo de escola de samba, no qual se basearam para propor a dramaturgia de Vargas:

O enredo é uma forma narrativa livre, aberta, que pode prescindir até mesmo da lógica formal, muito embora a sua característica de desfile pressuponha uma ordenação. Mas essa ordenação pode ser quebrada, subvertida, sem prejuízo de uma unidade e uma coerência próprias. Uma cena não precisa, necessariamente, ser uma consequência lógica da anterior. Do mesmo modo que inexiste qualquer compromisso com 0 realismo. $O$ anacronismo e a inadequação passam a ser

\footnotetext{
${ }^{2}$ Utilizarei enredo, em itálico, quando estiver me referindo não a um enredo de peça de teatro, isto é, a sua trama, mas ao enredo do desfile de escola de samba, que se configura de maneira diferenciada.
} 
elementos universalizantes. (GOMES, 1992, pp. 38-29)

Como se pode perceber, as palavras utilizadas para descrever 0 enredo aproximam-se do que hoje se observa em diversas peças modernas e contemporâneas: forma livre, aberta, sem lógica formal, desordem, anacronismo, inadequação, etc. Trata-se de uma forma da qual não se exige uma ordenação aristotélica, seus sentidos não estão calcados em uma coerência formal, mas na própria desordem que lhe é inerente. No caso dos desfiles, existe um padrão claro, convenções que são seguidas por todos os enredos. Trata-se, portanto, de um espetáculo quase teatral - não podemos chamar de teatro, porém, porque o ritual e a participação popular intensa, apaixonada e visceral, fazem dos desfiles uma manifestação diferenciada da arte cênica profissional.

Um desfile de escola de samba segue um padrão comum. Inicia-se com a comissão de frente: um bailado cênico, coreografado, que tem como objetivo apresentar a escola e saudar o público. Segundo o manual do julgador das escolas de samba de São Paulo: "A Comissão de Frente é o cartão de visita de uma Escola de Samba. É ela que estará anunciando o desfile" (LIGA, 2018, p. 10). Esse bailado cênico indica qual o tema do enredo. Antes da criação do sambódromo, quando as escolas desfilavam nas vias públicas, a comissão de frente abria caminho dentre os transeuntes para os cordões passarem. Em seguida à comissão segue-se todo o desfile, dividido em setores, separados por alegorias. A primeira alegoria (ou carro alegórico), o abre-alas, costuma vir próximo da comissão de frente: é o carro abre-alas, que também apresenta a escola, trazendo seu símbolo e seu nome estampados.

Geralmente cada setor apresenta uma parte do enredo e é formado por diferentes alas (grupos de sambistas que desfilam juntos). Não existe um número fixo de integrantes para cada ala, mas elas costumam ter mais ou menos 0 mesmo tamanho, proporcionando uma organização simétrica ao 
desfile. Podemos estimar que na cidade de São Paulo cada ala das grandes escolas é composta por cerca de cem integrantes. Eles vestem fantasias iguais ou, se não idênticas, relacionadas umas às outras, em harmonia (algumas alas integram mais de um tipo de fantasia). As alas menores muitas vezes têm um bailado específico, ou uma representação cênica, enquanto as maiores desfilam sambando ou com coreografias menos complexas, marcadas ao toque da bateria. Existem algumas alas típicas, como a das baianas, nas quais mulheres de idades variadas utilizam vestidos rodados e giram enquanto dançam; a da velha guarda, na qual desfilam os idosos da escola; e a bateria, ala na qual desfilam os ritmistas, duzentos no mínimo, em conjunto com os cantores e o carro de som que acompanha a escola.

Além das alas, o desfile apresenta os casais de mestre sala e porta-bandeira, sendo que o primeiro casal, o único avaliado pelos jurados, leva o pavilhão, símbolo maior da escola. A porta-bandeira carrega o pavilhão, e dança com a bandeira, como se a mesma fizesse parte de seu corpo; o mestre-sala tem o objetivo de proteger o pavilhão, mantendo-se o tempo todo ao redor da bandeira. Os dois apresentam a bandeira para o público. Sua dança é compassada e mistura a velocidade do samba (os bons mestres-salas parecem deslizar ao redor da bandeira) e a delicadeza do minueto.

$\mathrm{Na}$ cidade de São Paulo, os desfiles das maiores escolas têm mais de três mil integrantes, todos em comunhão ao atravessar a passarela do samba. A evolução, um dos quesitos avaliados, exige que todos os componentes, humanos e cenográficos, atravessem a pista como sendo um só. Descreve-se no manual:

Quando as Escolas de Samba
começaram a desfilar no centro da
cidade de São Paulo, o que mais
chamava atenção era sua
coreografia executada com a
maior naturalidade, baseada nos
batuques dos terreiros. Seus
movimentos para preencher os
espaços vazios era sambar,
serpenteando como uma grande
cobra, em um vai e vem contínuo.
(LIGA, 2018, p. 14)

Esse movimento de um deslocar contínuo, ritmado, dançado, conta uma história: o enredo do 
desfile. O narrar, conforme descrito pelos autores de Vargas, não tem a obrigação da ordem, da linearidade, ou de seguir quaisquer parâmetros de verossimilhança: o carnavalesco e sua escola são livres para sonhar. No entanto, ao selecionar um tema, isto é, um enredo, todo o espetáculo girará em torno dessa escolha:

O enredo é a base de tudo. A partir de sua escolha nasce a letra do samba, os figurinos (fantasias), as alegorias, etc., assim surgindo o roteiro para o desfile, dando vida à narrativa através da disposição das alas e do posicionamento dos Carros Alegóricos e personagens. (LIGA, 2018, p. 39)

\section{Enredos constantemente}

presentes são os que homenageiam uma personalidade - em 2018, das quatorze escolas do grupo especial de São Paulo, seis, isto é, quase a metade, basearam seus enredos na vida e obra de personalidades, vivas ou falecidas. Nesse caso, as alas e carros representam geralmente os lugares onde essas pessoas viveram, suas crenças, e sua obra ou legado. $O$ enredo não precisa seguir uma cronologia, muito menos ter um encadeamento causal entre suas alas, o que raramente acontece.
Muito comuns são os enredos que selecionam uma palavra e, a partir dela, cada ala remete a um derivado, a exemplo do enredo da Acadêmicos do Tucuruvi, de 2018, "Uma noite do museu", em que cada ala representava um tipo de museu diferente: de história, de ciências, de tecnologia, etc.; ou da Independente Tricolor, "Em cartaz: Luz, câmera e terror... Uma produção INDEPENDENTE!", em que cada ala era dedicada a um filme de terror. Tais enredos, no entanto, em geral, não alcançam conceber relações mais orgânicas entre as alas e os carros, mantendo-se num padrão de complexidade mais superficial e emocionando menos.

Isso não necessariamente indica que a escola terá uma pontuação menor. Na competição, o julgador não deve avaliar a complexidade da elaboração do enredo, sua capacidade para estabelecer metáforas ou criar um espetáculo que fuja ao senso comum e estenda seus significantes a fundamentos menos óbvios acerca do tema. No entanto, as escolas vencedoras são geralmente aquelas 
que encontram maneiras não somente de ir além da materialidade direta de referências e estabelecer conexões entre suas alas e alegorias, mas também de trazer um olhar diferenciado para os temas escolhidos. Tal conjuntura parece ser meramente aleatória, já que o julgador não irá despontuar escolas por apresentarem enredos óbvios, que não estabelecem tantas relações entre seus setores, ou que se mantêm num nível superficial de compreensão de seu tema. Entendese, porém, que subjacente ao modo como o enredo é concebido e executado, está sua força para emocionar os integrantes da escola, de cooptá-los, gerando um desfile que em tudo se sobressai, e que, ao final, não cometerá erros (os julgadores despontuam apenas os erros) e terá uma melhor classificação. Assim, a qualidade do enredo e o lugar em que a escola alcança na competição acabam por estabelecer uma correlação, não direta, mas sim subentendida.

A vencedora de 2017, Acadêmicos do Tatuapé (bicampeã em 2018), trouxe o enredo "Mãe África conta sua história: do berço sagrado da humanidade à abençoada terra do grande Zimbábwe". A concepção do tema alcançou expressar a ancestralidade do continente africano, exaltando a alegria. Ressalta-se daquele enredo o modo como a diferença de culturas presente nas inúmeras etnias, nações, povos que habitam 0 continente foi representada em cada ala - a ideia e sua execução na avenida alcançaram fugir ao lugarcomum do que se pensa sobre a África e sobre suas relações com o Brasil. Longe de estigmatizar a África como "uma só nação", o desfile mostrou com refinada composição a variedade presente no continente. $\mathrm{O}$ primeiro setor representava os diferentes povos, depois as religiões, no terceiro a arte, e no quarto diferentes referências como o povo shona (do Zimbábwe) e a colonização britânica.

Além disso, as fantasias não eram literais, expressavam metaforicamente cada povo a ser significado na passarela, ao utilizar cores e simbologias. Uma bem pensada paleta de cores fazia com que as alas se harmonizassem também entre si, compreendendo 
uma plástica de impressionante efeito visual. A relação com o Brasil ficava implícita em vários elementos do desfile: na ala do candomblé, do carnaval; nos destaques (como o rei congo), entre vários outros. Somada a essa maestria de concepção, o samba de enredo arrebatou todos os que estavam presentes no sambódromo, com uma métrica perfeita, uma sonoridade simples e arrebatadora, sem deixar de expressar o tema do enredo, e uma bateria com recursos sofisticados e bem ensaiada: todos cantaram.

O desfile de uma escola de samba é difícil de ser descrito com precisão. Trata-se de uma ópera popular com mais de três mil integrantes, todos em sintonia, que só pode acontecer de maneira plena quando existe uma comunidade de bairro ativa e unida por trás do desfile. Os ensaios acontecem no decorrer do ano e a assiduidade dos integrantes é fundamental para que o desfile saia com perfeição. Assim, se o espetáculo se estabelece em sessenta minutos, para nunca mais ser repetido (ou ser repetido apenas uma vez, no caso das escolas campeãs), o fato é que o desfile é o coroamento de uma vivência de diaa-dia, que integra, une, repercute nos bairros onde as escolas têm seus barracões. O desfile das escolas atinge a todos: os próprios integrantes, para quem o desfile começa na quadra e termina na quadra; a plateia e torcedores das arquibancadas; os julgadores; e a televisão, que transmite ao vivo os espetáculos. São quatro públicosalvo, todos contemplados plenamente por uma só cena.

No recente artigo "Do futebol ao carnaval: a metamorfose das torcidas organizadas em escola de samba na cidade de São Paulo", Bernardo Borges Buarque de Holanda (2018) analisou como a vivência das escolas tem alterado comunidades que giravam em torno de torcidas organizadas, trazendo para esses meios novas formas de articulação social. Escreve ele: "O ethos majoritariamente juvenil, masculino e viril do dia a dia do grupo dá lugar a outro, mais heterogêneo, que alguns chamariam de 'familiar'" (HOLANDA, 2018). Sem deixar de mencionar a ambiguidade 
violenta que rege as torcidas e que, claro, está presente também no meio das escolas, Holanda finaliza seu artigo com uma pergunta bastante positiva, que resume a importância e a força da cultura popular: "Não se deve ver neste fenômeno uma esperança, ainda que utópica, ensejada pela dinâmica da cultura popular, capaz de desconstruir toda espécie de rótulos e toda sorte de fatalismos que a normatividade jurídica e que o senso comum insistem em condenar?" (HOLANDA, 2018).

A esperança de Holanda, embora "utópica", serve de exemplo para indicar o quanto a arte popular, o espetáculo do povo, assume um lugar identitário, coletivo e individual, capaz de alterar a essência da convivência humana. Nesse sentido, em seus objetivos, o espetáculo distancia-se do teatro per se. O teatro também é ritualístico, cultural, identitário e também congrega e reúne. No entanto, o espetáculo do povo afasta-se do teatro enquanto arte autoral, arte experimental, realizada por um grupo de artistas (que podem e muitas vezes estão em comunhão com seu povo, mas que não é produzida coletivamente por esse povo). Os objetivos são outros, no teatro, em relação aos da festa.

Como já frisamos, o teatro brasileiro percebeu desde muito cedo a potência de tais espetáculos, seu poder de agregar um público cujo cotidiano está instaurado em tais festas, e sua força cênicoespetacular. Os desfiles de escola de samba são um exemplo, de magnitude ímpar, no entanto, tais formas espetaculares expandem-se em diferentes folguedos que acompanham a população no decorrer de todo o ano. Na história do teatro nacional, o diálogo com os folguedos e ritualidades, com as danças brasileiras, sempre existiu. Dias Gomes foi um dos dramaturgos com olhar refinado para essa espetacularidade, e desse olhar nasceu Vargas. A diferença entre teatro e folguedo fica mais clara quando utilizamos a peça como exemplo: Vargas não é um folguedo, é uma dramaturgia que foi encenada por atores e atrizes. A peça, porém, bebeu na fonte da festa popular, de onde se inspirou em forma e conteúdo. 


\section{Um texto a serviço da cena:}

\section{Vargas}

$\mathrm{Na}$ fase mais profícua de produção de textos teatrais de Dias Gomes, o trabalho com a cultura popular mostrou-se intenso. A partir de $O$ pagador de promessas, escrita em 1959 e encenada com retumbante sucesso em 1960 - peça que se tornou um marco do teatro moderno brasileiro -, a escritura de Gomes voltou-se para o diálogo com as formas nacionais de espetacularidade em diversos textos. O autor redimensionava a estrutura convencional de folguedos, ou os utilizava em alguns momentos das peças. No próprio $O$ pagador de promessas, a forma conversa com a teatralidade da Paixão de Cristo, segue a movimentação da cidade de Salvador, tem apresentação de capoeira, entre outros. Em $A$ revolução dos beatos (1961), a inspiração veio da festa do BoiBumbá, tanto na forma, como no conteúdo (Cf. NEVES, 2012). O berço do herói (1963) trabalha com música brasileira no final de quase cada quadro e lembra estruturalmente uma opereta. Ela se calca formalmente na vida de uma pequena cidade do interior, que acaba sendo 0 eixo de sua construção.

Conforme indicamos acima, o teatro, autoral, diferencia-se dos folguedos e festas (mesmo que tenham muitas semelhanças) pelos modos de produção e objetivos diferenciados. A carga de ritualidade e comunhão em geral é menor no teatro, porque os folguedos fazem parte da identidade coletiva de seus brincantes, enquanto no teatro geralmente a máscara se cria para aquele momento específico, concebida para cada encenação. Dias Gomes, dramaturgo, fazia uso das espetacularidades de sua cultura para elaborar uma dramaturgia que gera empatia com 0 público brasileiro. Os folguedos são a base para diferentes maneiras de se pensar a cena. No caso de Vargas, o texto é ainda mais rarefeito que o das peças citadas acima, porque está centrado numa cena musicada, bailada, performática. $\mathrm{A}$ dramaturgia está a serviço da espetacularidade, assim, quando apenas lida, ela exige 
do leitor um olhar diferenciado para o texto, capaz de vislumbrar a teatralidade de suas entrelinhas, o seu esgarçado devir cênico ${ }^{3}$.

Vargas intercala fragmentos de duas narrativas que, ao mesmo tempo em que se alternam, iluminam uma à outra. A peça é composta por falas versificadas e em prosa, narratividades e diálogos, canções e bailados. Está longe do drama hegeliano-aristotélico, mas se apoia em algumas personagens marcantes. As personagens não são complexas a ponto de suas personalidades intrigarem 0 espectador - elas estão mais próximas dos tipos do que de indivíduos. No entanto, existe singularidade forte na sua construção, principalmente porque cada uma se duplica nos dois enredos que compõem a dramaturgia.

Paradoxalmente, a fábula eixo se passa seguindo as unidades de tempo e de espaço. Tudo acontece durante um ensaio aberto do desfile, no qual a escola recebe turistas como público. Apesar de seguir

\footnotetext{
${ }^{3}$ Termo cunhado por Sarrazac (2012, pp. 6669).
}

essas unidades, o modo como a fábula se organiza está longe de ser concebido dentro das normas da piéce bien fait, do encadeamento causal, ou da clareza e ordem de continuidade. Primeiramente, são duas as fábulas entrelaçadas, que contaminam uma à outra, e, se uma se passa em uma noite, a outra se expande para alguns anos. A fábula que envolve a vida "real" dos integrantes da escola de samba segue as unidades de tempo e espaço, mas a fábula do enredo da escola se passa em diversos tempos e espaços. Em segundo, os cortes são constantes, para inserção de diversas cenas bailadas $e$ performáticas. Além disso, as personagens se dirigem continuamente à plateia.

A peça se passa em um dia de ensaio na quadra de uma escola de samba. Os integrantes da escola assumirão personas no enredo que a escola está preparando para o desfile de carnaval. Esse contará a vida de Getúlio Vargas, expresidente e ditador brasileiro, que governou o país entre 1930 e 1945, e depois entre 1951 e 1954, quando se suicidou. Como se vê, a peça segue 
uma estética comum às escolas: a homenagem a uma personalidade. A escola passa por graves problemas internos, há uma divisão entre seus integrantes, acarretada por questões administrativas e financeiras. $O$ antigo presidente, o bicheiro Tucão, perdeu o cargo depois de dez anos à frente da escola, porque foi vencido em eleição por Simpatia, que, além de ser agora o novo presidente, ainda the roubou a namorada, Marlene. Exasperado, Tucão deixa de financiar a escola e se move para recuperar o poder perdido e vingarse de Simpatia. Para tanto, ele finge aceitar a nova administração, para arquitetar, aos poucos, um plano capaz de quebrá-la: " $E$ tu pensas que eu to querendo brilhar? A minha jogada é outra... Sei o que faço" (GOMES, 1992, p. 45).

Essa narrativa é duplicada no enredo sobre Getúlio Vargas, que está sendo ensaiado pela escola. Simpatia representará Vargas no desfile, enquanto Tucão figurará como Carlos Lacerda - o maior adversário político do ex-presidente, um dos responsáveis pela crise que levou Vargas a se suicidar. Marlene desfila como Alzira Vargas, filha do presidente, que trabalhou como chefe de gabinete nos últimos anos de mandato do pai. Além dessas personagens protagonistas, o enredo conta com um personagem chamado de Autor, que irá apresentar o enredo e narrar os acontecimentos da vida de Getúlio.

A peça se inicia com uma explicação de Simpatia, em verso e cantada, pela qual ele transmite ao público as informações básicas sobre o espetáculo: o espaço é a quadra da escola; nele acontece um ensaio aberto do enredo que elegeram para o desfile daquele ano. Simpatia indica quem representará cada personagem e explica sua rixa com Tucão. Diz Simpatia: "O Ministério, com Oswaldo Aranha, Tancredo e outras altas patentes, é interpretado no enredo pela Comissão de Frente" (GOMES, 1992, p. 40). Em seguida, ele passa a palavra ao Autor, que escreveu o enredo para a escola, para que esse abra o espetáculo. 0 Autor informa:

\section{Elogio na cara deixa a gente encabulado, mas devo reconhecer}


que o enredo tá bem bolado

e que foi minha idéia

de a gente representar

algumas cenas, que assim

fica mais fácil de entender.

Já que está tudo explicado,

vamos aquecer o ambiente.

Atenção, a Bateria!

E a Comissão de Frente!

(GOMES, 1992, p. 41)

Nessa rápida apresentação, o Autor justifica ao público porque, no meio de um ensaio de desfile de escola de samba, no qual, por suas convenções, como vimos acima, não há falas nem cenas dialogadas (embora seja comum alas coreografadas e cênicas, que "contam" um trecho do enredo), isto é, em que tudo no enredo é representado alegoricamente, o mesmo deparará com a dramatização de algumas cenas sobre a vida de Getúlio. É nesse caminho que a peça se organiza estruturalmente. A partir dessa solução, que, mesmo sendo um pouco forçada se pensarmos numa esfera de verossimilhança (dificilmente os integrantes de uma escola ensaiariam um drama), um deus ex machina formal, os autores alcançam se apropriar do formato do desfile popular e, ao mesmo tempo, oferecer aos espectadores uma fábula complexa quando avaliada sob o prisma das relações entre as atuações das personagens, a trama envolvendo os integrantes da escola de samba, a história de Getúlio (inspirada em fatos reais), e a performatividade popular.

O espetáculo se inicia de fato nos moldes do desfile, com a entrada da Comissão de Frente da escola cuja elaboração de cena ficará a critério do diretor e dos atores bailando, encenando, apresentando a escola e saudando o público. No caso, a Comissão, como indicado por Simpatia, deve representar as altas patentes do governo getulista. Fosse o caso de um enredo real de uma escola, a escolha estaria perfeitamente compatível com a proposta de um desfile dentro dessa temática. Além disso, a peça começa com o entoar do samba-enredo, composto especialmente para 0 espetáculo (por Chico Buarque e Edu Lobo), e repetido em diversos momentos. O ensaio da Comissão é interrompido por Tucão, que, com ciúmes, tenta tirar Marlene da quadra - temos então uma cena dialogada, na qual outros integrantes defendem Marlene, e Tucão, antes de sair de 
cena, ameaça a moça e a escola, depreciando o enredo "comunista" escolhido para o desfile.

Então, o Autor interfere e chama à cena as primeiras alas, que representam a Revolução de 30:

Entra a primeira ala, que é a dos gaúchos. Vestidos a caráter, cavalgam pelo palco, iniciando o balé. Em seguida entram os paulistas, vestidos como bandeirantes, que, com espingardas boca-de-sino, investem contra os gaúchos. Eles lutam, entram os comunistas. São soldados barbados. Os gaúchos e os paulistas se unem contra eles, acabam por dominá-los e amordaçá-los. Em seguida colocam mordaças sobre as próprias bocas e desfraldam uma faixa: 1937 - ESTADO NOVO. Termina o balé. (GOMES, 1992, $p$. 50)

A rubrica descreve todo um bailado cênico, que representará desde a Revolução de 30 até o golpe de estado que tornou Getúlio um ditador. Se fosse um desfile de escola de fato, provavelmente seriam três alas que desfilariam uma após as outras: os gaúchos, os bandeirantes e os comunistas, seguidas talvez de um carro alegórico sobre o Estado Novo (período que foi de 1937 a 1945 , quando Getúlio renunciou na iminência de sofrer um golpe militar). $\mathrm{Na}$ peça, cabe à cena dar vida ao bailado, musicá-lo (o que poderia ser feito pela repetição do samba de enredo ad infinitum, como ocorre nos desfiles), e encenar as marcas de voltas e reviravoltas políticas marcadas na rubrica. Essa parte demonstra o quanto os efeitos de performático-musicais estão à frente do texto.

Em seguida ao bailado, entram em cena "três passistas fantasiados de águias, com enormes bicos", que representam "as 'Aves de rapina' de que fala 0 Presidente na carta que ele deixou" (GOMES, 1992, p. 51) antes de se suicidar. As aves são repreendidas pelo Autor, porque entraram no momento errado (o que acarretaria, no caso de um desfile real, em punição no quesito enredo). Três bicheiros, comparsas de Tucão, representam as águias. Eles tiram suas máscaras, dando início à segunda cena dialogada da peça, na qual os quatro conversam sobre a perda de poder de Tucão e esse continua o seu planejamento para recuperar o lugar de liderança junto à 
comunidade. A continuidade é interrompida novamente pelo Autor, que exige a volta dos ensaios, sendo o momento de entrar a performance da "Campanha Eleitoral".

Segue-se uma cena esfuziante que cobre cinco páginas de texto (da página 56 a 60). Nela se revezam mini-discursos políticos de Getúlio e de Lacerda (isto é, Simpatia e Tucão vestidos para o desfile), com cantigas populares entoadas por um coro nomeado como "Povo". A cena é dinâmica e divertida, porque as canções tornam-se irônicas quando entremeiam as curtas falas de teor político. São falas como: "Lacerda: Este homem não pode ser candidato; se candidato, não pode ser eleito; se eleito, não pode tomar posse; se tomar posse, faremos uma revolução para derrubá-lo" (GOMES, 1992, p. 56); e "Getúlio: Se for eleito em 3 de outubro, no ato da posse, o povo subirá comigo as escadas do Catete. E comigo ficará no Governo. Levaime, levai-me convosco" (GOMES, 1992, p. 59). As falas são entremeadas por versos do coro, que entoa, entre outros, canções carnavalescas diversas de teor semelhante a esse: "Povo: João
Mangabeira, João Mangabeira, vê lá se tu não fica na rabeira" (GOMES, 1992, p. 58).

A leitura do trecho não é fácil: não há ordenamento, sentido, relação causal entre as falas ninguém se ouve ou responde ao que foi dito, ninguém se dirige a ninguém e todos se dirigem ao público. Não se pode compreendê-la sem levar em consideração sua carga cênica, espetacular, e seu devir cênico. Quando se visualiza a potência de cena do trecho, percebese a maestria com que o mesmo foi concebido, seguindo a lógica (ou a ausência de lógica) da festa popular. Ao mesmo tempo, não se trata de falta de sentido, existe uma mensagem a ser transmitida, que se constrói exatamente porque está colocada no âmbito dessa aparente ausência de lógica: os dois políticos se digladiam, mas a voz do povo, que é zombeteira, alegre e direta, a voz cantada do povo, acaba tendo a palavra final nessa situação, quando o voto direto se efetiva, e Getúlio é eleito. Em paralelo, faz-se a alusão ao que se passou na própria escola, quando Simpatia - que encarna Getúlio - foi eleito, e Tucão - que 
encarna Lacerda - almeja mover céus e terras para derrubar seu rival.

A peça, porém, está apenas no começo. Em seu desenrolar, o enredo dramatizado apresentará as contradições do governo getulista, suas lutas e dificuldades. $O$ expresidente é apresentado como herói. As divergências históricas são mencionadas no decorrer do espetáculo somente pela fala do antagonista Tucão. O golpe final, que levou Getúlio ao suicídio, é explicado na peça como tendo sido propositalmente articulado por Lacerda - em paralelo aos planos ardilosos de Tucão para derrubar Simpatia. A história do governo eleito de Getúlio é apresentada em cenas curtas dialogadas, nas quais suas decisões são mostradas ao espectador: cena do presidente com sua filha, que recomenda cuidado na escolha de ministros; com 0 embaixador dos EUA, a quem as medidas sobre o petróleo, a contenção ao imperialismo, desagradam; com 0 ministro Oswaldo Aranha, sobre o impasse gerado pela lei do petróleo e a ameaça dos rivais políticos do presidente.

Enquanto isso, Lacerda investe na desmoralização do Governo. Uma fala da personagem chama a atenção não só porque os autores estão se referindo ao golpe militar de 1964, mas também pela atualidade impressionante em relação ao evento recente de impeachment da presidente Dilma Rousseff, ocorrido em 2016. Será que o Brasil jamais escapará desse malfadado eterno retorno?

A fala é apresentada pela personagem do Autor sob o título de "Como se depõe um Presidente":
É simples,
Em primeiro lugar,
É preciso levantar
A bandeira moralista:
Mostrar que o Governo é corrupto,
Composto de chantagistas,
De ladrões,
De rufiões,
Cafetões e vigaristas,
De tubarões,
Charlatães,
Maganões,
De descuidistas.
É muito importante.
Com a bandeira moralista,
Ganha-se então por inteiro
A famosa classe-média,
Que sonha ter virtudes
$O$ que lhe falta em dinheiro.
E como a virtude é rara
E difícil de provar, 
Torna-se fácil apontar

Corrupção no Governo.

Gatunagem,

Malandragem,

Ladroagem,

Tratantagem. (GOMES, 1992, pp. 90-91)

Independentemente da

liberdade fictícia da peça - que deixou de lado os aspectos mais nebulosos e negros dos governos getulistas -, como resultado artístico, se avaliamos a peça de maneira isolada de seus contrapontos históricos, chama atenção a crítica política, presente de forma forte em todas as peças de Gomes. Apresenta-se ao público contemporâneo, nessa peça escrita há quase trinta e cinco anos, a ironia da roda viva brasileira, isto é, da repetição de acontecimentos políticos no país.

E remete direta e novamente à festa popular, no ano de $2018 \mathrm{em}$ específico, quando uma escola de samba do Rio de Janeiro, a Paraíso do Tuiuti, apresentou o enredo "Meu Deus, meu Deus, está extinta a escravidão?" e chamou atenção com um destaque de carro alegórico que representava o presidente vestido como vampiro e uma ala indicando o papel da classe média na destituição da presidente anterior.

Cabe aqui lembrar a frase emblemática de Daniel Marques da Silva: "O que salva o Brasil é a festa" ${ }^{4}$. No meio dessa desordem nacional, o Brasil se organiza por meio da festa, que não é apenas um momento de divertimento ou de "esquecer os problemas". A festa, no Brasil, é um meio de expressão, de identidade, conhecimento, comunicação e, principalmente, de luta e de resistência. Vargas, como peça teatral, apreende esse patamar mais visceral da representatividade da festa popular na sociedade brasileira, e traz uma interpretação política que parece calcada num evento histórico, mas que, na verdade, discute a sociedade brasileira de maneira mais aprofundada.

Os principais dilemas do governo de Getúlio e as artimanhas de Lacerda são encenados em cenas rápidas e musicadas, que alternam a entrada de alas, como a "ALA DOS

4 Frase proferida em palestra na mesa redonda Dramaturgias (Im)possíveis (In)viáveis, ocorrida no VII Simpósio Internacional Reflexões Cênicas Contemporâneas, no dia 22 de fevereiro de 2018. 
LANTERNEIROS, todos portando, como alegorias de mão, enormes lanternas coloridas", ao estilo próprio dos desfiles carnavalescos. Quando Lacerda sofre uma suposta tentativa de assassinato, no qual morre um oficial da aeronáutica, iniciam-se cenas dialogadas, nas quais se mostra como Getúlio será aos poucos encurralado politicamente. $\mathrm{Na}$ escola, o mesmo se passa com Simpatia: parte das alas se recusa a desfilar, se Tucão não reassumir a presidência. A estrutura da peça traça com inteligência a conexão entre as duas fábulas, como se pode observar no trecho abaixo - o cerco se fecha para Getúlio, e paralelamente se fecha também para Simpatia:

Alzira (com sarcasmo): O povo... o povo já está gritando nas ruas "Abaixo Getúlio", o mesmo povo que trouxe o senhor nos braços até aqui. Que é que o senhor pode esperar de um povo assim?

Tumulto fora de cena.

Coro (fora): Fora Simpatia!

Fora Simpatia! (GOMES, 1992, p. 127)

Como se vê, Alzira informa a Getúlio que perdeu o apoio da população, e a voz do povo que surge em seguida é aquela que almeja derrubar Simpatia. Seguemse duas cenas dialogadas, na primeira, Simpatia conversa com os amigos, que o incentivam a fugir, porque Tucão está decidido a matálo se não se afastar da escola. $\mathrm{Na}$ segunda, Getúlio conversa com seus aliados, para entender as opções que the restam para salvar seu Governo. Após uma rápida interferência cantada de Tucão, a peça segue para o final, com 0 suicídio de Getúlio e o assassinato concomitante de Simpatia. Entra uma alegoria que deve representar o leito presidencial. Após a encenação dos últimos momentos de vida do presidente, quando the é anunciado que será deposto, Simpatia/ Getúlio lê sua carta-testamento. Após a leitura, Tucão entra em cena com seus comparsas e fuzilam Simpatia, "ainda com a carta na mão".

A peça termina de maneira apoteótica. A última fala, antes de o Autor encerrar o espetáculo, é de Marlene, que diz:

Eles pensam que venceram Mas não nos venceram não. São movidos pelo ódio, 
Mas nós temos outra paixão.

Não procuramos a morte

Mas a vida, a alegria.

Essa paixão mais forte, que a tudo desafia. (...). (GOMES, 1992, p. 154)

A cena é emocionante, porque Marlene está debruçada sobre 0 corpo recém-morto de Simpatia. Aí está fortemente expressa a ideia indicada acima, de que a festa, no Brasil, significa luta, resistência, "que a tudo desafia". Não se trata apenas de alegria sem sentido, mas de resiliência. O povo, quando se reúne em suas festividades, encarna a força de manter-se vivo e de pé, encarando as atrocidades de frente, aquelas que acontecem todos os dias no Brasil.

Vargas é composta nesse espírito, adquirindo um nível de crítica bastante complexo, porque, se a mensagem direta da peça favorece a batalha por um Governo menos corrupto, e mais justo, batalha essa que no Brasil parece nunca avançar; suas camadas de sentido trazem, no paralelo entre o governo federal e a organização de uma comunidade, orquestrada pelo desfile da festa popular, um poder de reflexão muito mais intenso. A reflexão sobre os desafios de se manter um coletivo, de se enfrentar o poder autoritário, e de como a festa no Brasil é arma de luta e, ao mesmo tempo, ferramenta de comunhão.

Recebido em 27/07/2018

Aceito em 10/10/2018

\section{Referências Bibliográficas}

CAMPOS, Cláudia de Arruda. Zumbi, Tiradentes. São Paulo: Perspectiva, 1988.

GOMES, Dias. Coleção Dias Gomes: os espetáculos musicais. Vol. 4. Rio de Janeiro: Bertrand S. A., 1992.

LIGA das Escolas de Samba de São Paulo. Manual do Julgador. 2018. Disponível em: <https://ligasp.com.br/releases/manu al-julgador2018.pdf> Acesso em 20/02/2018.

HOLANDA, Bernardo Borges Buarque de. "Do futebol ao carnaval: a metamorfose das torcidas organizadas em escola de samba na cidade de São Paulo". Disponível em:

$<$ http://www.ludopedio.com.br/arquib ancada/futebol-carnaval/> Acesso em 20/02/2018.

MACHADO, Alcântara. Palcos em foco. (org. Cecília de Lara). São Paulo: EDUSP, 2009.

MERCADO, Antonio. "Coleção Dias Gomes". In. GOMES, Dias. Coleção Dias Gomes: os espetáculos 
musicais. Vol. 4. Rio de Janeiro:

Bertrand S. A., 1992. pp. 7-15.

NEVES, Larissa de Oliveira. O Bumba-meu-Boi em A revolução dos beatos, de Dias Gomes. Anais do VIl Congresso da ABRACE. Porto Alegre: ABRACE, 2012.

SARRAZAC, Jean-Pierre. Léxico do drama moderno e contemporâneo.

São Paulo: Cosac \&Naify, 2012. 
Moringa Artes do Espetáculo, João Pessoa, UFPB, v. 10 n. 1, jan-jun/2019, p. 67 a 88

\section{moringa}

